Limnol. Rev. (2016) 16, 4: 213-219

DOI 10.1515/limre-2016-0023

\title{
Export of nutrients from the catchment of the upper Szeszupa River (drainage basin of the Neman River) and its seasonality
}

\author{
Andrzej Górniak \\ Department of Hydrobiology, University of Białystok, Ciołkowskiego 1J, 15-254 Białystok, Poland; e-mail: hydra@uwb.edu.pl
}

\begin{abstract}
The article presents the dynamics of concentrations and export of nitrogen, phosphorus, TOC in the upper Szeszupa River (tributary of the River Neman) in the period from 2000 to 2014 (15 years) based on monthly analyses performed in Poland in the scope of the National Environmental Monitoring. The lakeland river with a mean discharge of $1.6 \mathrm{~m}^{3} \mathrm{~s}^{-1}$ and catchment dominated by agricultural land exports approximately $20 \mathrm{~kg} \mathrm{ha}^{-1}$ of organic carbon compounds per year. The export of nitrogen is insignificant $\left(3.8 \mathrm{~kg} \mathrm{ha} \mathrm{m}^{-1}\right) \mathrm{with} 55 \%$ accounting for the element in the form of organic compounds and $31 \%$ for nitrates. Phosphorus export is also relatively low $\left(0.12 \mathrm{~kg} \mathrm{ha}{ }^{-1}\right)$, with $30 \%$ of the load of TP constituted by orthophosphates. During four months (February-May), 40-60\% of annual export of nutrients was discharged, whereas the load of nitrates and organic nitrogen was higher than the contribution of outflowing water. From 2010, an increasing tendency has been observed in organic nitrogen export. This may be related to the intensification of animal production in NE Poland and an increase in livestock density.
\end{abstract}

Key words: river, export, nitrogen, phosphorous, organic carbon

\section{Introduction}

The progressing anthropogenic eutrophication of surface waters is one of the processes limiting the resources of utility waters suitable for municipal or household use (Wetzel 2001). This is particularly important in areas with small groundwater resources. Apart from economic consequences, water eutrophication has a substantial impact on changes in the structure of hydrobionts of aquatic ecosystems, causing a decrease in biodiversity and lowering natural resistance to stress (Hillbricht-Ilkowska 2005). The processes of anthropogenic water fertilisation in areas under legal protection are considered as the leading factor in the assessment of the efficiency of planned protection measures, which is of importance in landscape parks. The co-existence of environmentally valuable areas and agricultural land is inherent in the functioning of this form of protection in Poland.

In the preliminary phase of studies on water eutrophication it was believed that nitrogen and phosphorus are responsible for a progressive increase in phytomass in rivers and lakes. With time it appeared that silicon and organic carbon compounds also contribute to an increase in water productivity (Williamson et al.
1999). Changes in the amount of N, P, Si, and C compounds, together called "ecosystem drivers", occur in the case of their excessive supply to the catchment in the form of fertilisers, sewage, or gases. Besides direct biological monitoring of waters, the balance of biogene substances in a catchment is the best indicator of the rate of fertilisation of aquatic ecosystems. The assessment of the inflow of loads that lead to eutrophication and their retention in a catchment poses serious methodological and analytical difficulties. Therefore, the analysis usually concerns the resultant of a complex of phenomena in the form of determination of loads of biogenes leaving the catchment. Irrespective of the applied methods of estimation of export of biogenes in the catchment and the applied models (e.g. HELCOM, MONERIS, and HYPE models), obtained results are becoming an important instrument of regional ecological policy.

To date, performed estimations of the export of nitrogen and phosphorus have only concerned Polish rivers in the drainage basin of the Baltic Sea, omitting rivers flowing outside Poland. The River Szeszupa in the drainage basin of the River Neman is an example. Its upper section is located in the Suwałki Lakeland, also constituting a hydrographic axis of the Suwałki 
Landscape Park (SLP). The existing data on the aquatic environment permit the determination of biochemical changes occurring in the catchment as a result of protection measures, but also resulting from progressing climatic changes, and changes in the agricultural activity of the region observed in the landscape. The findings of Romanowska-Konopko (2006) as well as earlier studies of Hillbricht-Ilkowska (1994) showed the river to be in a good ecological state with only inconsiderable hydrochemical changes in the waters under the prevailing conditions of an extensive agricultural economy in the catchment.

The objective of the paper was to estimate the export of biogenes from the catchment of the River Szeszupa and its seasonality in a period of 15 years (2000-2014). The analyses also covered the export of organic carbon compounds, omitted in research so far, as an important indicator of processes of hydrosphere eutrophication.

\section{Study area}

The River Szeszupa in NE Poland is the upper part of a river flowing through Lithuania, constituting a tributary of the lower River Neman in the drainage basin of the Baltic Sea (Fig. 1). Therefore, it has the character of a trans-border river. In the territory of Poland, it drains the diverse landscape of a young-glacial lakeland from the Baltic glaciation built of clays, sands, and gravels. Beneath the layer of Pleistocene sediments with a thickness of approximately $300 \mathrm{~m}$, a thin (300-400 m), for the conditions of Central Europe, complex of Mesozoic and Palaeozoic rocks is deposited on Precambrian metamorphic rocks. The shallow occurrence of crystalline bedrock, with advanced tectonics, contributed to the Pleistocene neotectonic transformations of glacial sediments, the specific cratonic system of groundwaters (Mitręga et al. 1993), and neotectonic conditions of numerous lakes (Ber 2000). The Pleistocene underground glaciation has not yet finished, and permafrost was recorded recently in the eastern part of the catchment at a depth of 370$380 \mathrm{~m}$ (Honczaruk and Śliwiński 2011). The surface catchment $\left(186 \mathrm{~km}^{2}\right)$ and the river, with a length of 19 $\mathrm{km}$, has a SW-NE orientation and mean relative altitude of $194 \mathrm{~m}$ a.s.l. The catchment is covered by a mosaic of cambic and podzoluvic soils developed from carbonate sandy or loamy soils, calcaric cambisols on sandy gravels, and valley complexes of fluvisols and histosols, frequently deposited on limnic formations with a thickness of more than 10-12 m (Gałka and Apolinarska 2014).

The catchment of the upper River Szeszupa undergoes climatic conditions typical of the transitional zone between the climate of the boreal zone and Central European zone of mixed forests. Mean air temperature in the area amounts to approximately $7^{\circ} \mathrm{C}$, and annual precipitation total to $600-650 \mathrm{~mm}$ (Górniak 2000). The studied catchment represents a fluvial-limnic system with stable and little variable fluvial discharge in the course of a year, and a higher than average unit outflow of more than $8 \mathrm{dm}^{3} \mathrm{~s}^{-1} \mathrm{~km}^{-2}$ (BajkiewiczGrabowska 2002). In the analysed profile, it is a river of the third order with a mean slope of $4.1 \%$, whereas the slope of the catchment amounts to $5.8 \%$. The mean density of the fluvial network equals $0.45 \mathrm{~km} \mathrm{~km}^{-2}$. It has four permanent tributaries and the largest one, the River Wigra, constitutes $25 \%$ of the area of the entire catchment (Fig. 1). The River Szeszupa flows through five lakes. The largest of the 54 lakes of the catchment,

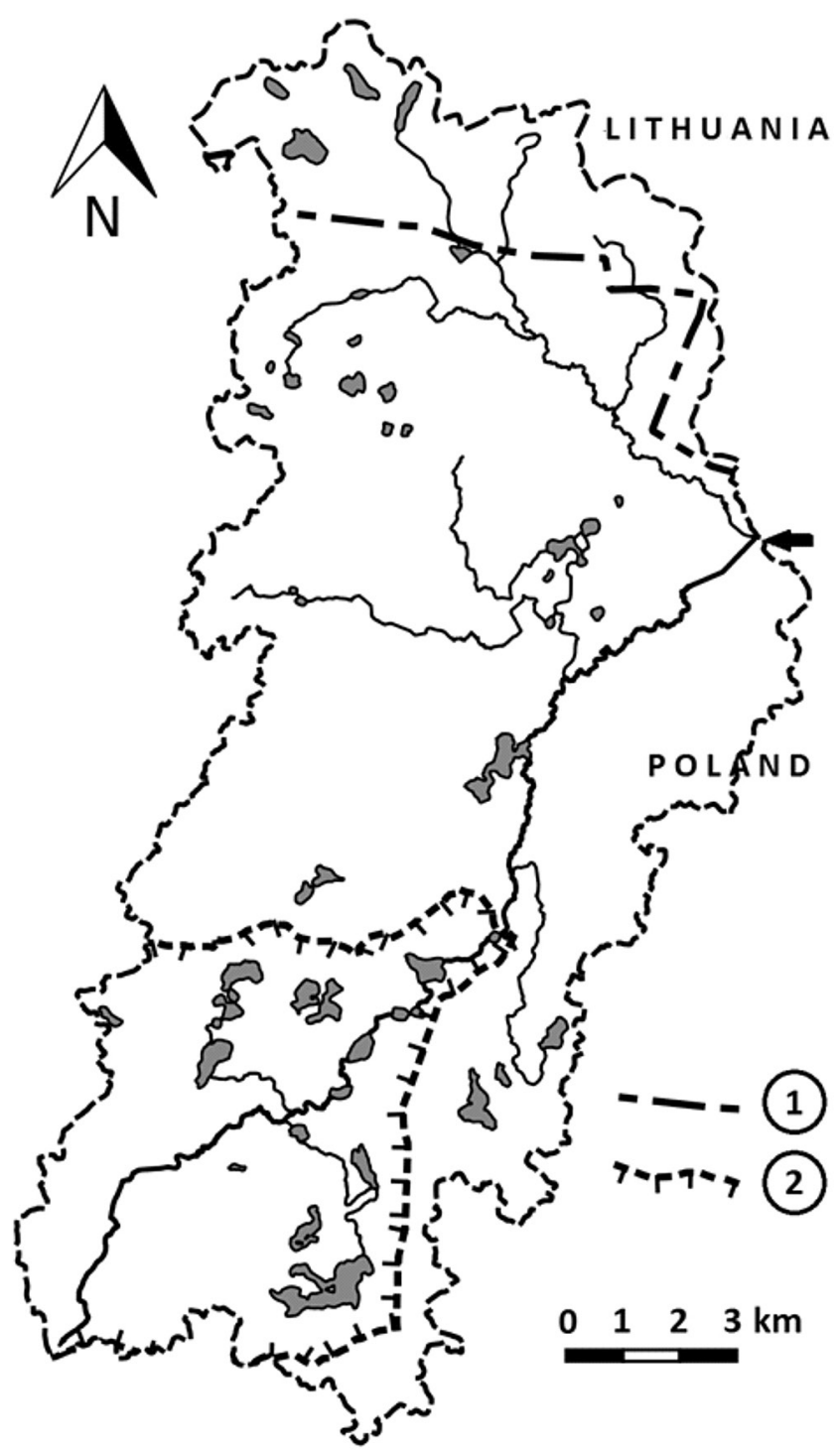

Fig. 1. Map of the upper Szeszupa River catchment. Explanation: 1 border between Poland and Lithuania, 2 - Suwałki Landscape Park 
Lake Szurpiły (84 ha), is the source of the Szurpiłówka Stream, a right-bank tributary of the main river. The drainage area of the river is predominantly under agricultural use (71\% arable land). Forests constitute only $15 \%$ of the area. The population density is low (40 people per square kilometer), with no industrial plants present. Consequently, the rivers and majority of lakes in the catchment are of a good ecological state. The river shows a chemical composition subject to a low level of transformation (Hillbricht-Ilkowska 1994; Romanowska-Konopko 2006). Due to the richness of post-glacial forms of landscape, 53 lakes, high biological diversity, and relatively low air pollution, the Suwałki Landscape Park was established in 1976, covering a major part of the Szeszupa catchment. The area was included among the NATURA 2000 protected areas.

\section{Methods}

The analysed data were obtained from the $\mathrm{Na}$ tional Water Monitoring conducted by the accredited laboratory of the Voivodship Inspectorate for Environmental Protection (WIOS) in Bialystok, branch in Suwałki. They cover results of monthly analyses of the waters of the River Szeszupa in the Poszeszupie profile over a period of 15 years (calendar years 2000-2014). For measurements for the years 2000-2003 performed every two weeks, mean monthly concentrations were calculated, and missing data were supplemented by mean values from the neighbouring terms. Electrolytic conductivity $\left(\mathrm{EC}\right.$ in $20^{\circ} \mathrm{C}$ ), temperature, $\mathrm{pH}$, and oxygen concentration were determined directly in the field by means of electrometric methods. Concentrations of nitrates, ammonium ions, and forms of phosphorus were predominantly determined by means of colorimetric methods. From 2007, ammonium ions, nitrates, and orthophosphates (SRP) were determined by chromatographic methods using a conductance detector in order to make a comparison with earlier colorimetric methods. Kjeldahl nitrogen ( $\mathrm{NKj}$ ) and total phosphorus (TP) were determined after prior mineralisation. Concentrations of organic nitrogen (Norg) were calculated from the difference between Kjeldahl nitrogen (Norg $\left.=\mathrm{NKj}-\mathrm{N}-\mathrm{NH}_{4}\right)$. Total nitrogen constituted the sum of Kjeldahl nitrogen and nitrates $(\mathrm{TN}=\mathrm{NKj}$ $+\mathrm{N}-\mathrm{NO}_{3}$ ). Determinations of TOC by instrumental methods commenced after 2005. For the earlier period, this was calculated from the correlation between oxidisability (permanganate method) and TOC concentrations, similarly to in studies concerning rivers and lakes in Finland (Kortelainen 1993). Mean monthly discharges for the research profile were obtained from the Institute of Meteorology and Water Management (IMGW) in Warsaw.
The loads of nutrients were calculated for 180 months. Mean monthly concentrations of the analysed nutrients provided in this paper are weighed values compared to discharges, i.e. a ratio of mean load of a given element and mean discharge for calendar years and months. The method is used for obtaining values of loads from research with a high frequency of field analyses, or research with the application of data obtained from continuous measurements (De Klein and Koelmans, 2011).

\section{Results}

\section{Hydrology and nutrient concentrations}

According to the data of the Institute of Meteorology and Water Management, the mean annual discharge of the river in the period from 2000 to 2014 amounted to $1.6 \mathrm{~m}^{3} \mathrm{~s}^{-1}$, and specific discharge $8.6 \mathrm{dm}^{3}$ $\mathrm{s}^{-1} \mathrm{~km}^{-2}$. The highest mean monthly discharge occurred in March $\left(2.4 \mathrm{~m}^{3} \mathrm{~s}^{-1}\right)$, and the lowest in August (0.99 $\left.\mathrm{m}^{3} \mathrm{~s}^{-1}\right)$. The variability of discharges was the highest in September (Fig. 2).

Mean annual temperature of riverine water showed low fluctuations, and in the study period amounted to $8.5^{\circ} \mathrm{C}$ (Table 1), with the highest mean in July $\left(18.0 \pm 2.0^{\circ} \mathrm{C}\right)$ and lowest in February $\left(0.5 \pm 0.5^{\circ} \mathrm{C}\right)$.

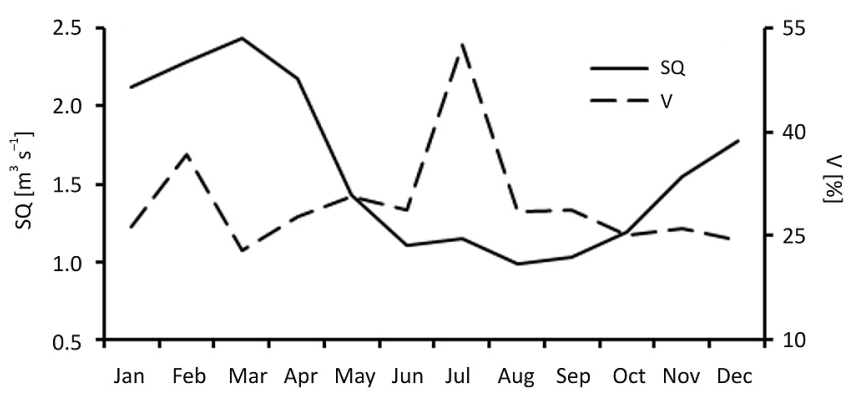

Fig. 2. Monthly mean discharge (SQ) and monthly variability of discharges (V) of the River Szeszupa in the years 2000-2014

Table 1. Average and variability of the investigated water parameters of the River Szeszupa in years 2000-2014; V - index of variability [\%] (all data)

\begin{tabular}{|c|c|c|c|c|c|}
\hline Parameter & units & mean & $\min$. & $\max$. & $\mathrm{V}$ \\
\hline Temperature & ${ }^{\circ} \mathrm{C}$ & 8.5 & -0.1 & 22.8 & 43 \\
\hline Oxygen & $\mathrm{mg} \mathrm{O}_{2} \mathrm{dm}^{-3}$ & 10.8 & 7.6 & 15.0 & 16 \\
\hline Conductivity & $\mu \mathrm{S} \mathrm{cm}^{-1}$ & 418 & 255 & 493 & 11 \\
\hline TOC & $\mathrm{mg} \mathrm{C} \mathrm{dm}^{-3}$ & 7.37 & 1.0 & 18.5 & 31 \\
\hline $\mathrm{TN}$ & \multirow{4}{*}{$\mathrm{mg} \mathrm{N} \mathrm{dm}^{-3}$} & 1.20 & 0.45 & 4.15 & 45 \\
\hline $\mathrm{N}-\mathrm{NO}_{3}$ & & 0.37 & 0.05 & 2.04 & 88 \\
\hline $\mathrm{N}-\mathrm{NH}_{4}$ & & 0.17 & 0.06 & 0.43 & 35 \\
\hline Norg & & 0.66 & 0.10 & 3.81 & 60 \\
\hline TP & \multirow{2}{*}{$\mu \mathrm{g} \mathrm{P} \mathrm{dm^{-3 }}$} & 40.9 & 7.0 & 165 & 48 \\
\hline SRP & & 11.3 & 1.2 & 56.7 & 62 \\
\hline TOC : Norg & non dimentional & 13.5 & 1.0 & 54.4 & 60 \\
\hline
\end{tabular}




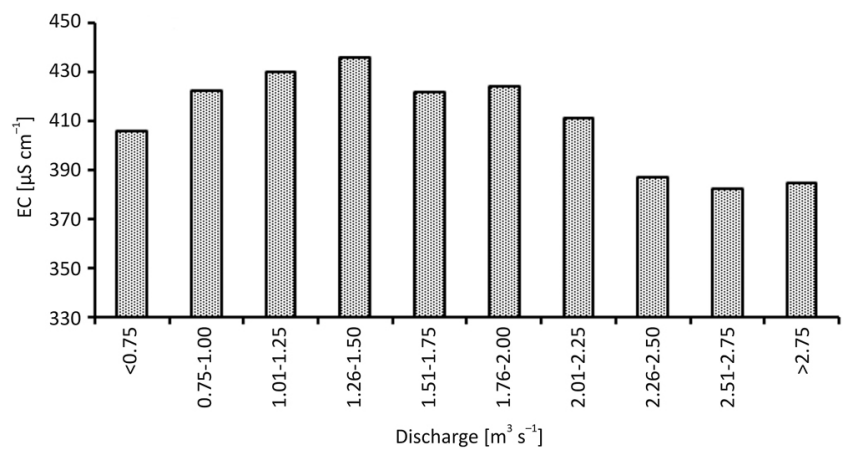

Fig. 3. Correlations between mean monthly discharge and water conductivity in the River Szeszupa in the years 2000-2014

Waters of the River Szeszupa were always oxygenated (10.8 $\mathrm{mg} \mathrm{O}_{2} \mathrm{dm}^{-3}$ on average), with oxygen saturation varying from 73 to $113 \%$. The mean value of electrolytic conductivity (EC) of water equalled $418 \mu \mathrm{S} \mathrm{cm}-1$ with a range of variability shifted towards lower values. At discharges lower than $1.0 \mathrm{~m}^{3} \mathrm{~s}^{-1}$ and higher than 2.25 $\mathrm{m}^{3} \mathrm{~s}^{-1}$, EC values decreased, and were lower than at average discharges (Fig. 3).

The recorded range of TOC concentrations was quite broad (Table 1), similarly to the range of annual means. Monthly means were quite uniform (6.55 to $8.21 \mathrm{mg} \mathrm{C} \mathrm{dm}^{-3}$ ) with the lowest concentrations in September and October, and the highest in March.

The physical-chemical water parameters were characterised by variability lower than that of forms of
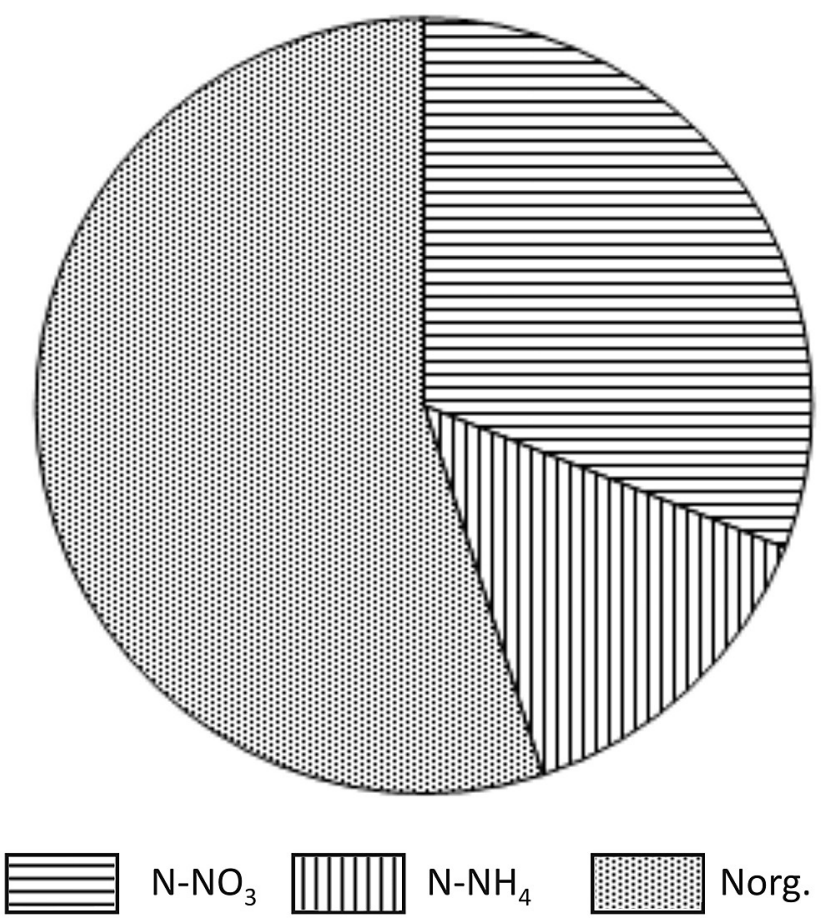

Fig. 4. Mean contribution of the analysed forms in total nitrogen in the River Szeszupa in the years 2000-2014
Table 2. Characteristics of export of nutrients from the River Szeszupa in the years 2000-2014

\begin{tabular}{|c|c|c|c|c|c|}
\hline \multirow{2}{*}{ Parameter } & \multirow{2}{*}{ unit } & Year & \multicolumn{3}{|c|}{ Monthly } \\
\hline & & mean & mean & $\min$. & $\max$. \\
\hline TOC & \multirow{5}{*}{$\mathrm{kg} \mathrm{ha}^{-1}$} & 20.6 & 1.72 & 0.21 & 4.83 \\
\hline $\mathrm{TN}$ & & 3.78 & 0.31 & 0.05 & 1.28 \\
\hline $\mathrm{N}-\mathrm{NO}_{3}$ & & 0.47 & 0.11 & 0.05 & 0.75 \\
\hline $\mathrm{N}-\mathrm{NH}_{4}$ & & 0.52 & 0.04 & 0.01 & 0.16 \\
\hline Norg & & 1.95 & 0.17 & 0.01 & 0.85 \\
\hline TP & \multirow{2}{*}{$\mathrm{gP} \mathrm{ha}^{-1}$} & 121 & 10.1 & 21 & 580 \\
\hline SRP & & 33 & 2.8 & 0.3 & 13.5 \\
\hline
\end{tabular}

nitrogen and phosphorus, where the variability coefficient was higher than $45 \%$, with the exception of ammonium ions. Moreover, ammonium ions had the lowest contribution among forms of nitrogen (14\%), with a definite predominance of organic nitrogen (Fig. 3).

Norg concentrations revealed a uniform course in a year, with a slight decrease in the mean values in September and October (Fig. 4). Concentrations of nitrates in the cool half-year (December-April) were 3-4 times higher than those in the summer season (Fig. 5). This form of nitrogen turned out to be the most variable among the analysed water parameters (Table 1). The coefficient of the quality of organic matter transported by the river, calculated as the ratio of TOC/Norg, amounted to 13.5 on average, whereas values of the ratio in the spring period (February-May) were statistically significantly lower than values form the period from July to October: $12.7( \pm 0.8)$ and 15.0 $( \pm 0.7)$, respectively.

Total phosphorus concentrations (TP) occurred in a range from 7 to $165 \mu \mathrm{g} \mathrm{P} \mathrm{dm}{ }^{-3}$ (Table 1 ). In the au-
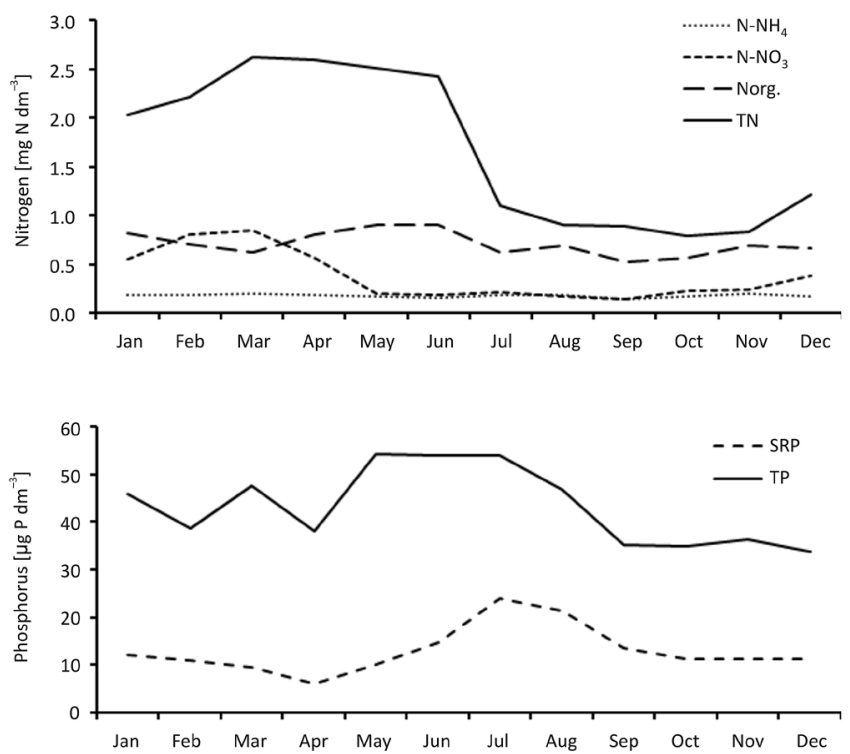

Fig. 5. Variability of nitrogen (upper panel) and phosphorus (lower panel) forms in the River Szeszupa in the period 2000-2014; mean weighed data 
tumn period, TP concentrations were lower by $30-40 \%$ than in the spring period. In the annual course, the lowest mean monthly concentrations of orthophosphates (SRP) were recorded in April, and the highest - in July (Fig. 5) when they constituted $40 \% \mathrm{TP}$, and in the remaining period $25-30 \%$.

\section{Riverine export of dissolved solids and nutrients}

The annual water transport of organic carbon compounds reaches the mean level of $2 \mathrm{t} \mathrm{C} \mathrm{km}^{-2}$. In the course of the year, higher than average export is observed between December and April and almost three times lower export from the period from August to October. TN export was lower by an order of magnitude than TOC where export of forms of organic nitrogen dominated over nitrates and ammonium ions. The seasonality of analysed nitrogen forms in a year corresponded with the rhythm of water outflow from the catchment. The maximum of export of nitrates and ammonium ions is recorded in March, and organic nitrogen in April (Fig. 6). The highest variability of elution among forms of nitrogen was observed
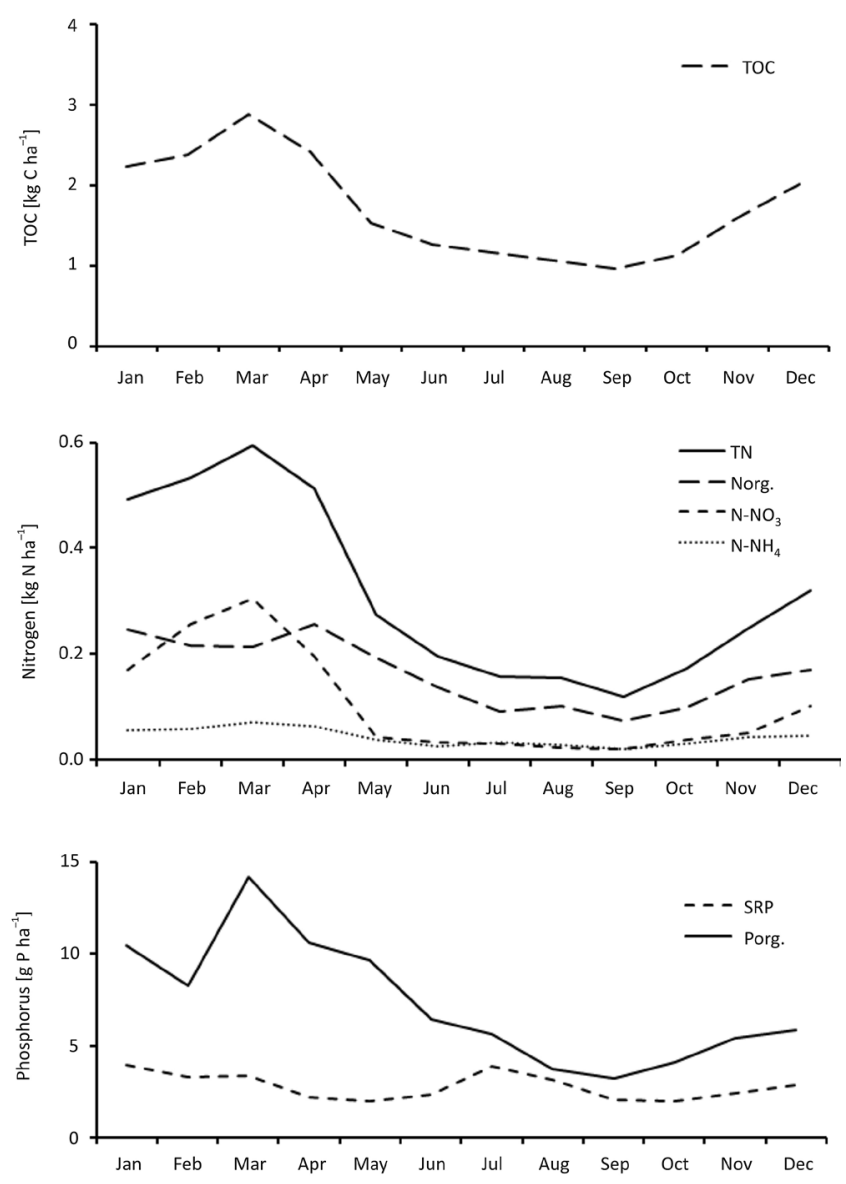

Fig. 6. Mean monthly chemical denudation, TOC and nutrient export from the River Szeszupa in the years 2000-2014
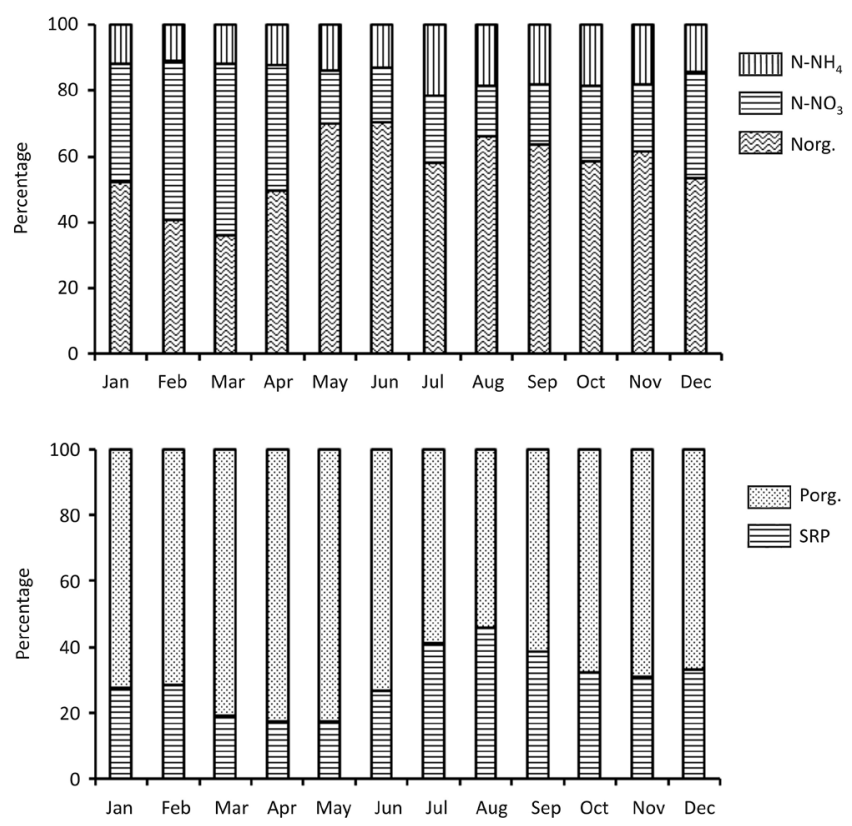

Fig. 7. Mean monthly nutrient structure in the export of total nitrogen (upper panel) and total phosphorus (lower panel) from the Szeszupa River catchment in the years 2000-2014

for nitrates, and the lowest for ammonium ions. The contribution of nitrate nitrogen in TN export in spring (February-April) was approximately twice as high as in the remaining part of the year (Fig. 7). The contribution of ammonium ions in TN export was higher in the period from June to November than in the remaining part of the year.

Seasonal changes in phosphorus export particularly concerned Porg. Mean monthly values of orthophosphates export showed low variability with an inconsiderable maximum in July (Fig. 6) when they constituted approximately $40 \%$ of TP export (Fig. 7). Mean monthly values of Porg export were directly proportionate to Norg export (Fig. 8).

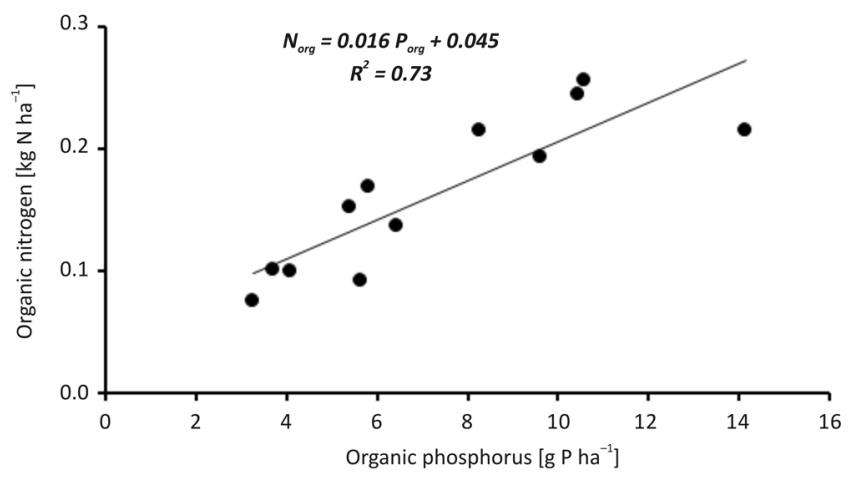

Fig. 8. Correlation between mean monthly organic phosphorus (TP minus SRP) and organic nitrogen export from the River Szeszupa catchment in the years 2000-2014 


\section{Discussion}

Export of matter from river catchments of the moderate zone is particularly determined by the amount of discharged water, constituting a resultant of the regional water balance, and climatic factors. The amount of export of nutrients in the River Szeszupa from the years 1999-2001 presented by Romanowska-Konopko (2006) was 50-60\% higher than in the multiannual 2000-2014. This was associated with the humid years of these studies with discharges exceeding mean values from the multiannual. Moreover, an inefficient wastewater treatment plant had functioned in the catchment during the earlier period, which is currently is being modernised.

Current export of nutrients from the Szeszupa catchment is lower in comparison to other catchments of Polish lakelands. The calculated values of TN and TP export are considerably lower than those presented for other rivers of northern Poland in spite of the high dominance of arable land ( $>70 \%)$ in the catchment (Table 3). This suggests a reduced, for Polish conditions, atmospheric load of TN and TP in the catchment, estimated for 3-10 kg N ha-1 and 0.1-0.6 kg P ha-1, respectively (data for Suwałki from the period 2000-2014 according to http://powietrze.gios.gov.pl/pjp/home). In spite of the slowly increasing level of fertilisation of arable land in Poland after 2000, no increased fluvial export of nutrients is observed in larger rivers. The value remains at a similar level (Ilnicki 2014). In the Szeszupa catchment, however, from 2010, a tendency of increased export of TN, and particularly Norg, has been observed at a relatively low increase in annual discharges (Fig. 9). This is presumably related to an increase in overland flow in the vegetative season, including a higher than average amount of organic matter from arable land, as well as faeces left on pastures by the rise in livestock of cattle in NE Poland. In the discussed period of 15 years in the Podlaskie voivodship, the cattle population grew by $42 \%$, and the cattle livestock density increased by $58 \%$ (from 56 to 88 livestock units $100 \mathrm{ha}^{-1}$ ). The common trend of a decrease in fluvial export of nutrients in Poland from the mid 1990's results from the

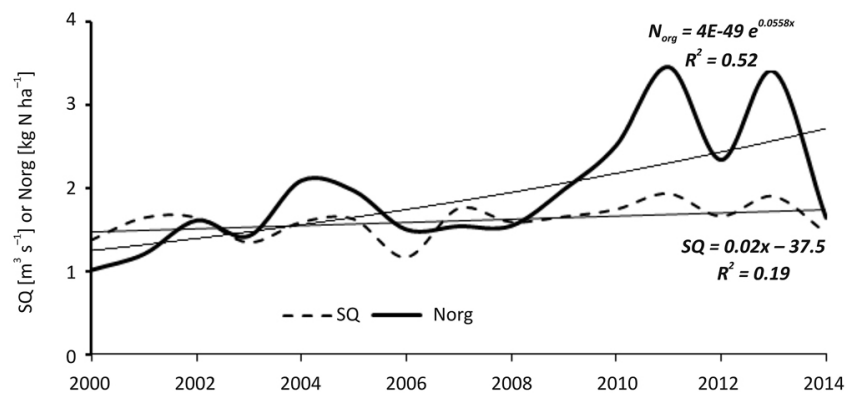

Fig. 9. Tendencies of organic nitrogen export and annual discharge in the River Szeszupa catchment in calendar years 2000-2014

construction of numerous wastewater treatment plants (Pastuszak and Igras 2012). Untreated wastewater is the primary factor responsible for the degradation of aquatic ecosystems (Pastuszak et al. 2012).

The little transformed, macrophyte rich fluvial network plays an important role in limiting the export of nutrients in the Szeszupa catchment. De Klein and Koelmans (2011) documented the substantial retention of nutrients in catchments of Western Europe, amounting to $23-84 \% \mathrm{~N}$ and $39-72 \% \mathrm{P}$, respectively. Povilaitis et al. (2012) studying rivers of Estonia and Lithuania evidenced that catchment retention of nutrients is higher in lakes than in rivers.

The changing thermal-precipitation character of the cool period determined by climatic changes in NE Poland (Górniak 2000) has largely modified the current regime of nutrient export. Similarly, according to the performed analyses, an increase in the frequency and rate of summer heavy rainfalls causes an increase in the export of organic nitrogen. Therefore, the intensifying effects of climatic changes and increase in the intensification of agriculture in NE Poland, particularly cattle breeding, will require further studies to be undertaken.

\section{References}

Bajkiewicz-Grabowska E., 2002, Obieg materii w ekosystemach rzeczno-jeziornych (Circulation of matter in riverlake ecosystems), Wydaw. UW, Warszawa, 274 pp. (in Polish, English summary).

Table 3. Comparison of mean annual export of nitrogen and total phosphorus by selected rivers of central and northern Poland

\begin{tabular}{|c|c|c|c|c|}
\hline \multirow{2}{*}{ River } & \multirow{2}{*}{ Station } & \multicolumn{2}{|c|}{ Export $\left[\mathrm{kg} \mathrm{ha}^{-1}\right]$} & \multirow{2}{*}{ References } \\
\hline & & TN & TP & \\
\hline Prosna & Ruda Pomorska & 7.3 & 0.28 & Ilnicki (2014) \\
\hline Ner & Chełmno & 12.4 & 0.72 & Ilnicki (2014) \\
\hline Warta & Oborniki & 6.9 & 0.28 & Ilnicki (2014) \\
\hline Brda & Męcikał & 4.3 & 0.20 & Bogdanowicz and Cysewski (2008) \\
\hline Zbrzyca & Zbrzyca & 4.1 & 0.11 & Bogdanowicz and Cysewski (2008) \\
\hline Wielka Struga & Paszkówka & 5.6 & 0.12 & Popek et al. (2014) \\
\hline Szeszupa & Poszeszupie & 3.8 & 0.12 & this study \\
\hline
\end{tabular}


Ber A., 2000, Plejstocen Polski północno-wschodniej w nawiązaniu do głębszego podłoża i obszarów sąsiednich (Pleistocene of north-eastern Poland and neighbouring areas against crystalline and sedimentary basement), Pr. PIG 170: 1-89. (in Polish, English summary).

Bogdanowicz R., Cysewski A., 2008, Transformation of riverine nutrients load in selected lakes of the Zaborski Landscape Park, Limnol. Rev. 8(1-2): 13-19.

De Klein J.J.M., Koelmans A.A., 2011, Quantifying seasonal export and retention of nutrients in West European lowland rivers at catchment scale, Hydrol. Processs 25(13): 2102-2111.

Gałka A., Apolinarska K., 2014, Climate change, vegetation development, and lake level fluctuations in Lake Purwin (NE Poland) during the last $8600 \mathrm{cal}$. BP based on a highresolution plant macrofossil record and stable isotope data $\left(\delta^{13} \mathrm{C}\right.$ and $\left.\delta^{18} \mathrm{O}\right)$, Quat. Int. 328-329: 213-225.

Górniak A., 2000, Klimat województwa podlaskiego (Climate of Podlaskie Voivodeship). Wydaw. IMGW, Warszawa, 119 pp. (in Polish).

Hillbricht-Ilkowska A., 1994, Ocena ładunku fosforu i stanu zagrożenia jezior Suwalskiego Parku Krajobrazowego oraz niektóre zależności pomiędzy ładunkiem a wskaźnikiem trofii jezior (Evaluation of the phosphorus load and degree of endangerment, of lakes in Suwałki Landscape Park, and some relationhips between the load and the indices of the status of lakes), [in:] HillbrichtIlkowska A., Wiśniewski R.J. (eds) Jeziora Suwalskiego Parku Krajobrazowego. Związki z krajobrazem, stan eutrofizacji i kierunki ochrony (Lakes of the Suwałki Landscape Park. Links with landscape, eutrophication and protection measures), Zesz. Nauk. Kom. Nauk. PAN "Człowiek i Środowisko" 7: 201-214 (in Polish, English summary).

Hillbricht-Ilkowska A., 2005, Ochrona jezior i krajobrazu pojeziernego - problem, procesy, perspektywy (Protection of lakes and lakeland landscape- problems, processes, perspectives), Kosmos 54: 285-302 (in Polish).

Honczaruk M., Śliwiński Ł., 2011, Wyniki badań hydrogeologicznych w strefie występowania głębokiej wieloletniej zmarzliny w otworze wiertniczym Udryń PIG1 (Results of hydrogeological research of the deep permafrost zone in the Udryn PIG borehole) Biul. PIG 445: 203-216 (in Polish, English summary).

Ilnicki P., 2014, Emissions of nitrogen and phosphorous into rivers from agricultural land- selected controversial issues, J. Water Land Dev. 23(4): 31-39.

Kortelainen, P., 1993, Content of total organic carbon in Finnish Lakes and its relationship to catchment characteristics, Can. J. Fish. Aquat. Sci. 50(7): 1477-1483.

Mitręga J., Paczyński B., Płochniewski Z., 1993, Wody podziemne Suwalszczyzny (Groundwaters of Suwałki Region). Prz. Geol. 41(8): 569-574 (in Polish, English summary).

Pastuszak M, Igras J. (eds), 2012, Temporal and spatial differences in emission of nitrogen and phosphorous from Polish territory to the Baltic Sea, Nat. Mar. Fish. Res. Inst, Inst. Soil Sci. Plant Cultiv., Gdynia-Puławy, 448 pp.

Pastuszak, M., Stålnacke P., Pawlikowski K., Witek Z., 2012, Response of Polish rivers (Vistula, Oder) to reduced pressure from point sources and agriculture during the transition period (1988-2008), J. Mar. Syst. 94: 157-173.

Popek Z., Wasilewicz M., Bańkowska A., Boczoń A., 2014, Sezonowa zmienność odpływu wody i ładunków biogenów ze zlewni Wielkiej Strugi do Jeziora Zadworskiego (The seasonal variation of the runoff of water and biogenic matter from the Wielka Struga river basin to the Zadworskie Lake, Poland), Monogr. Kom. Gosp. Wod. PAN 20(2): 341-354 (in Polish, English summary).

Povilaitis A., Stalnacke P., Vassiljev V., 2012, Nutrient retention and export to surface waters in Lithuanian and Estonian river basins, Hydrol. Res. 43(4): 359-373.

Romanowska-Konopko E., 2006, Transport substancji biogennych rzeką Szeszupą (Transport of biogenic substances in Szeszupa River), Wiad. IMGW 29(1): 3-14 (in Polish, English summary).

Wetzel R.G., 2001, Limnology. Lake and river ecosystems, Academic Press, San Diego, 1006 pp.

Williamson C.E., Morris D. P., Pace M.L., Olson O.G., 1999, Dissolved organic carbon and nutrients as regulators of lake ecosystems: Resurrection of a more integrated paradigm, Limnol. Oceanogr. 44(3, part 2): 795-803. 